\title{
Integrasi Servqual, Kano dan QFD dalam Meningkatkan Kualitas Pelayanan di Sekolah Tinggi XYZ
}

\author{
Abdul Fatah ${ }^{1}$, Teguh Aprianto ${ }^{2}$ \\ 1,2)Program Studi Teknik Industri, Sekolah Tinggi Teknologi Bandung \\ Jl. Soekarno Hatta No. 378, Bandung 40235 \\ Email: abdulfatah@sttbandung.ac.id,gerakantanganmu417@gmail.com
}

\begin{abstract}
The service quality at XYZ High School is still not in accordance as expected. There are still queues for registration, payments, length of academic service, parking capacity, lecture room, library access, security, and etc. This study is conducted to find out the service quality of XYZ high school towards the students' satisfaction. The methods used in this research are the integration method of Servqual, Kano and Quality Function Deployment (QFD), using 5 Servqual dimensions, those are Tangible, Reliability, Responsiveness, Assurance, and Empathy. The gap value of all service attributes provided is negative. It means that the service performance still can't fulfill the students' expectation. Based on the integration calculation of the Servqual, Kano and QFD methods, there are 16 of 31 service attributes need to be improved. The easy attribute in accessing information by online can become priority with the important level of 23.17 by constructing an online integrated information to become the priority technical response which is conducted for the improvement with the percentage of $21.04 \%$.
\end{abstract}

Keywords: service quality, kano, quality function deployment

\begin{abstract}
Abstrak
Kualitas pelayanan di Sekolah Tinggi XYZ masih belum sesuai dengan apa yang diharapkan, misalnya masih terjadi antrean pendaftaran, pembayaran, lamanya pelayanan akademik, daya tampung parkir, ruang kuliah, akses perpustakaan, keamanan, dan lain-lain. Pada penelitian ini bertujuan untuk mengetahui kualitas pelayanan Sekolah Tinggi XYZ terhadap kepuasan mahasiswa. Adapun metode yang digunakan pada penelitian ini adalah metode integrasi Servqual, Kano dan Quality Function Deployment (QFD), dengan menggunakan 5 dimensi Servqual, yaitu Tangible, Reliability, Responsiveness, Assurance, dan Empathy. Nilai gap seluruh atribut pelayanan yang diberikan bernilai negatif yang berarti kinerja pelayanan masih belum mampu memenuhi harapan dari mahasiswa. Berdasarkan perhitungan integrasi metode Servqual, Kano dan QFD, atribut pelayanan yang perlu dilakukan perbaikan sebanyak 16 dari 31 atribut pelayanan. Atribut mudah dalam memperoleh informasi secara online menjadi prioritas dengan nilai importance level 23,17 dengan membangun pusat informasi terpadu secara online menjadi prioritas respons teknis yang dilakukan untuk perbaikan dengan bobot $21,04 \%$.
\end{abstract}

Kata kunci: service quality, kano, quality function deployment

\section{Pendahuluan}

Era revolusi industri 4.0 adalah satu tahapan masa yang hadir dengan membawa gelombang yang disebut disrupsi yaitu suatu kondisi dimana perubahan yang terjadi di dunia industri berlangsung sangat cepat, mendasar, dan bahkan terkesan mengaduk-aduk pola lama untuk menghasilkan tatanan baru. Inovasi demi inovasi dalam segala sektor industri tersebut mau tidak mau juga telah masuk ke ranah pendidikan, sehingga kemudian muncul pilihan bagi pendidikan yaitu untuk berubah atau musnah. Digitalisasi dalam dunia pendidikan dapat kita lihat melalui adanya 
konsep digital learning, online courses, e-book, dan sistem informasi akademik terpadu. Pada pendidikan tinggi, digital learning merupakan wujud disrupsi pendidikan yang memiliki kemampuan untuk mengubah secara mendasar bagaimana proses pembelajaran (Hartanto et al., 2019)

Kepuasan pelanggan memiliki pengaruh positif dan signifikan terhadap keputusan untuk menggunakan layanan dan merupakan faktor utama dalam menentukan daya saing industri dan seiring dengan kemajuan teknologi juga akan berdampak pada persaingan yang semakin ketat dan memberikan peluang besar bagi konsumen untuk menemukan produk berkualitas dengan harga relatif terjangkau (Oktafiara et al., 2017).

Sebuah organisasi harus senantiasa meningkatkan kualitas pelayanannya terhadap konsumen, agar mampu bersaing dengan perusahaan lain. Semakin banyak konsumen terpenuhi kebutuhannya, semakin besar kemungkinan konsumen tersebut menjadi pelanggan, yang akan kembali lagi untuk mendapatkan produk atau jasa yang kita berikan. Karena persepsi dan harapan setiap konsumen berbeda, maka perusahaan harus benar-benar mengetahui apa yang sebenarnya konsumen inginkan dan mengetahui prioritas dari beberapa dimensi kualitas pelayanan yang harus dipenuhi. Banyak aspek yang menjadi pertimbangan seseorang dalam menentukan sebuah produk atau jasa. Selain harga dan kualitas dari barang itu sendiri, juga mempertimbangkan kualitas pelayanan yang diberikan. Tidak sedikit barang-barang atau jasa yang berkualitas tetapi tidak bisa bertahan lama dikarenakan kualitas pelayanan yang buruk.

Adanya Revolusi Industri 4.0 menjadi tantangan tersendiri bagi pendidikan tinggi di Indonesia. Perguruan tinggi harus mampu menyesuaikan dengan perkembangan Revolusi Industri 4.0, misalnya reorientasi kurikulum, metode pembelajaran, penggunaan teknologi informasi, infrastruktur, sarana, dan prasarana lainnya. Kondisi ini memaksa Sekolah Tinggi XYZ untuk senantiasa melakukan perbaikan di berbagai bidang, agar kualitas pelayanan terhadap para pihak terkait khususnya mahasiswa menjadi lebih baik.

Sekolah Tinggi $\mathrm{XYZ}$ selama beberapa tahun terakhir mengalami kenaikan mahasiswa yang signifikan, sehingga pihak lembaga harus mampu meningkatkan kualitas pelayanan terhadap mahasiswa agar kebutuhannya terpenuhi. Dengan bertambahnya mahasiswa, mengakibatkan beberapa masalah, seperti terjadinya antrean pada saat pembayaran, luas lahan parkir yang tidak mencukupi, pelayanan akademik yang masih kurang memuaskan, ketersediaan buku-buku di perpustakaan, dan lain-lain. Oleh sebab itu, peneliti tertarik untuk melakukan penelitian terhadap kualitas pelayanan di Sekolah Tinggi XYZ. Sehingga dapat mengetahui prioritas dari kualitas pelayanan yang harus ditingkatkan sesuai dengan keinginan dari mahasiswa.

\section{Metodologi}

\section{Tinjauan Literatur}

Kualitas merupakan suatu kondisi dinamis yang berpengaruh dengan produk, jasa, manusia, proses dan lingkungan yang memenuhi atau melebihi harapan. Sehingga definisi kualitas pelayanan dapat diartikan sebagai upaya pemenuhan kebutuhan dan keinginan konsumen serta ketepatan penyampaiannya dalam mengimbangi harapan konsumen (Tjiptono, 2011). Kualitas layanan atau service quality (SQ) dalam konseptual kontemporer adalah perbandingan dari harapan yang dipersepsikan $(E)$ dengan kinerja layanan yang dirasakan $(P)$, sehingga menimbulkan persamaan $S Q=P$ - E. Konseptualisasi kualitas layanan ini berawal pada paradigma harapan yang tidak terpenuhi. Sebuah bisnis dengan kualitas layanan yang tinggi akan memenuhi atau melebihi harapan pelanggan sementara tetap kompetitif secara ekonomi. Bukti dari studi empiris menunjukkan bahwa peningkatan kualitas layanan dapat meningkatkan profitabilitas dan daya saing ekonomi jangka panjang. Peningkatan kualitas layanan dapat dicapai dengan meningkatkan operasional proses, mengidentifikasi masalah dengan cepat dan sistematis, membangun validitas dan keandalan pengukuran kinerja layanan, pengukuran kepuasan pelanggan, dan hasil kinerja lainnya (Tam et al., 2017).

Kualitas pelayanan memiliki beberapa dimensi atau unsur kualitas pelayanan. Unsurunsur kualitas pelayanan merupakan hasil penelitian dari teori kualitas pelayanan yang disampaikan oleh A. Pasuraman dan kawankawan. Sebagai salah satu tokoh pionir dalam pengukuran kualitas pelayanan, Pasuraman 
mencetuskan lima dimensi servqual (Parasuraman et al., 1985) yaitu tangibles, reliability, responsiveness, assurance, dan empathy.

Metode Servqual dibangun atas adanya perbandingan dua faktor utama yaitu persepsi pelanggan atas layanan yang nyata mereka terima (Perceived Service) dengan layanan yang sesungguhnya diharapkan oleh pelanggan (Expected Service). Selisih antara persepsi dengan harapan disebut dengan "Gap". Kegagalan dalam penyampaian jasa dapat didefinisikan ke dalam 5 gap (kesenjangan), yaitu: Gap 1 merupakan kesenjangan antara harapan pelanggan dan persepsi manajemen, Gap 2 merupakan kesenjangan antara persepsi manajemen dan spesifikasi kualitas jasa, Gap 3 merupakan kesenjangan antara spesifikasi kualitas jasa dan penyampaian jasa, Gap 4 merupakan kesenjangan antara penyampaian jasa dan komunikasi eksternal, dan Gap 5 merupakan kesenjangan antara jasa yang diterima pelanggan dan jasa yang diharapkan (Parasuraman et al, 1990)

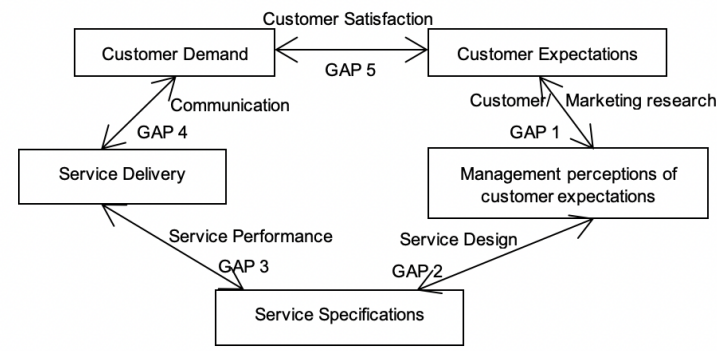

Gambar 1. Gap model of service quality (Jing-Hua et al., 2009)

Model Kano dikembangkan oleh Noriaki Kano pada tahun 1984. Model Kano merupakan suatu model yang bertujuan mengategorikan atribut-atribut dari produk atau jasa berdasarkan seberapa baik produk/jasa tersebut mampu memuaskan kebutuhan pelanggan (Wijaya, 2018). Atribut-atribut layanan dalam Model Kano dibedakan menjadi beberapa kategori (Chen et al., 2008):

a. Must be atau basic quality

Merupakan kriteria dasar yang harus dipenuhi. Pelanggan akan kecewa apabila kinerja atribut pelayanan yang diberikan rendah atau atribut pelayanan dihilangkan. Tetapi tidak terlalu memberikan kepuasan berlebih walaupun dengan meningkatkan kinerja atribut pelayanan.

b. One-dimensional atau performance quality

Kategori ini bersifat linier artinya jika kinerja atribut pelayanan tinggi maka akan mendorong tingginya tingkat kepuasan pelanggan. Begitu pula sebaliknya, jika kinerja atribut pelayanan rendah maka tingkat kepuasan pelanggan akan menurun.

c. Attractive atau excitement quality Kepuasan pelanggan akan naik secara signifikan dengan meningkatnya kinerja atribut pelayanan. Namun pelanggan tidak akan kecewa jika atribut pelayanan tersebut tidak diberikan.

d. Indifference

Kepuasan pelanggan tidak akan terpengaruh kinerja dari atribut pelayan.

e. Reverse

Pelanggan semakin tidak puas dengan meningkatnya kinerja atribut pelayanan.

f. Questionable

Kadang kala konsumen merasa puas atau tidak puas jika atribut pelayanan diberikan/tidak diberikan.

QFD dikembangkan di Jepang oleh Yoji Akao pada tahun 1972 (Gupta \& Srivastava, 2012). QFD (Quality Function Deployment) adalah salah satu alat kualitas yang digunakan untuk meningkatkan kepuasan pelanggan dengan menerjemahkan kebutuhan pelanggan ke kebutuhan teknis. Selain itu, QFD juga digunakan untuk memberikan inovasi perbaikan dalam rangka untuk meningkatkan kepuasan pelanggan. QFD memungkinkan penyedia jasa untuk memprioritaskan kebutuhan pelanggan, menentukan tanggapan atas kebutuhan pelanggan, dan menentukan prioritas perbaikan untuk mencapai efektivitas maksimum.

Bagian terpenting dalam QFD adalah membangun house of quality (HOQ). HOQ berfungsi sebagai matriks perencanaan produk yang terdiri dari kebutuhan pelanggan, kebutuhan teknis, dan analisis kompetitor. Singkatnya, HOQ memberikan informasi tentang penetapan target dan prioritas perbaikan (Hartono et al., 2013). House of Quality (HOQ) adalah salah satu matrix pada metode QFD (Quality Function Development) yang digunakan untuk menerjemahkan 
kebutuhan pelanggan ke dalam persyaratan teknis yang harus dipenuhi.

Pembuatan $\mathrm{HOQ}$ terdiri dari tujuh langkah (Baki et al., 2009), yaitu :

a. Mendefinisikan Voice of customer atau customer need (whats)

b. Mendefinisikan tingkat prioritas konsumen (customer priority level)

c. Penilaian kompetitor (competitive assement)

d. Menentukan aspek teknis yang diperlukan (technical requirement) (hows)

e. Membuat relationship matrix

f. Membuat correlation matrix

g. Menentukan target value

Gambar 2 berikut menunjukkan bagianbagian dari house of quality.

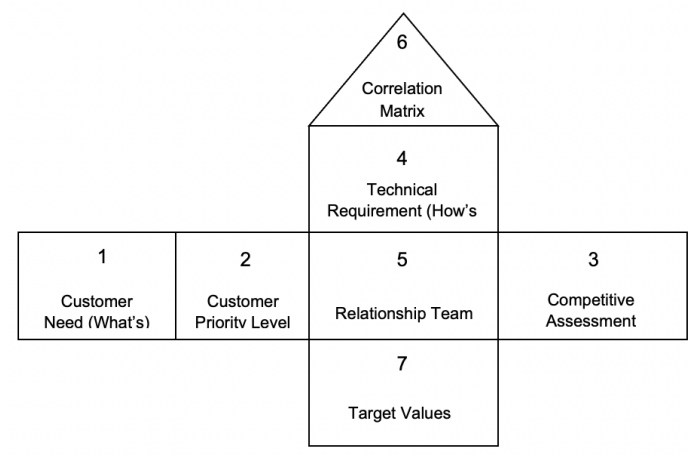

Gambar 2. House of quality (HOQ)

(Russel \& Taylor, 2003)

\section{Urgensi Integrasi metode Servqual, Kano dan QFD}

Konsep servqual digunakan untuk mengetahui gap antara persepsi dengan ekspektasi atau harapan konsumen. Kepuasan konsumen dapat dicapai dengan memberikan kualitas pelayanan yang baik. Oleh sebab itu perusahaan harus mengetahui pelayanan yang diinginkan dan diharapkan konsumen. Untuk dapat memberikan pelayanan yang dibutuhkan dan diharapkan konsumen dapat menggunakan metode QFD. QFD menerjemahkan apa yang dibutuhkan pelanggan menjadi apa yang dihasilkan perusahaan.

Namun, keinginan konsumen bisa berbeda-beda, oleh sebab itu perusahaan harus mengetahui atribut-atribut produk atau jasa berdasarkan seberapa baik produk/jasa tersebut mampu memuaskan kebutuhan konsumen. Sehingga integrasi servqual dan metode Kano dapat dilakukan sebagai input/voice of customer dalam metode QFD.
Pengintegrasian konsep servqual dan Kano ke dalam QFD dapat dilihat pada Gambar 3.

Dengan mengintegrasikan konsep Servqual ke dalam QFD, maka QFD bertindak sebagai proses perencanaan untuk menerjemahkan kebutuhan pelanggan ke dalam persyaratan organisatoris. Penerapan QFD dapat mengurangi waktu desain sebesar $40 \%$ dan biaya desain sebesar $60 \%$ secara bersamaan dengan dipertahankan dan ditingkatkannya kualitas desain (Wijaya, 2018).

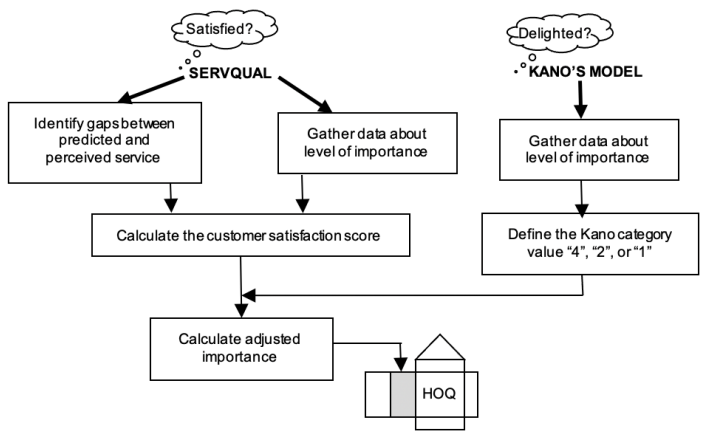

Gambar 3. Kerangka integrasi servqual dan kano ke dalam QFD

\section{Alur Penelitian}

Untuk mempermudah memecahkan persoalan yang dihadapi, perlu diuraikan terlebih dahulu langkah-langkah yang diperlukan untuk memecahkan masalah tersebut. Tahapan-tahapan metodologi penelitian ini digambarkan seperti berikut:

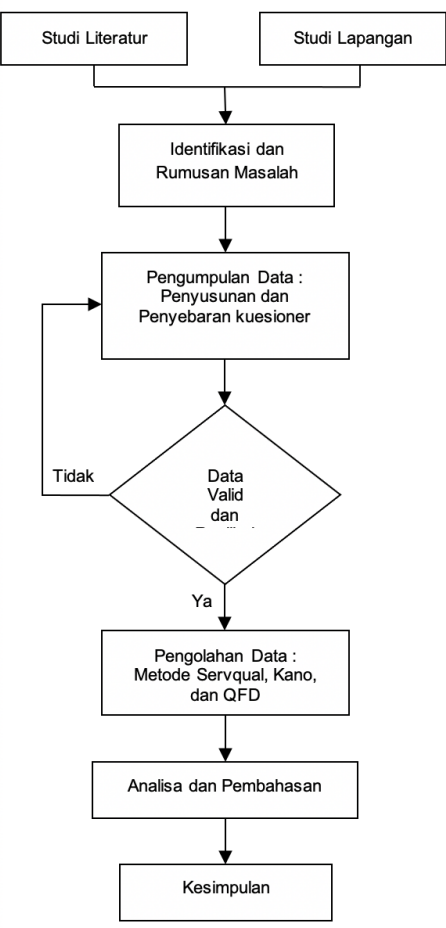

Gambar 4. Alur penelitian 


\section{Pengumpulan Data}

Data yang digunakan dalam penelitian ini adalah data hasil penilaian kuesioner dari mahasiswa Sekolah Tinggi XYZ angkatan 2016. Pembuatan kuesioner menggunakan google forms. Sedangkan penyebaran kuesioner dilakukan secara online, dikarenakan kondisi saat ini yang masih pandemi Covid 19.

a. Kuesioner Servqual
Atribut dalam kuesioner Servqual menggunakan pendekatan 5 dimensi Servqual dari Parasuraman, yaitu: Tangible (bentuk fisik), Reliability (Keandalan), Responsiveness (Ketanggapan), Assurance (Jaminan), dan Empathy (Empati). Terdiri dari 31 atribut pertanyaan.

Adapun atribut pertanyaannya adalah sebagai berikut pada Tabel 1 .

Tabel 1. Kuesioner servqual

\begin{tabular}{|c|c|c|c|c|c|c|c|c|c|c|c|c|}
\hline \multirow{2}{*}{ No. } & \multirow{2}{*}{$\begin{array}{l}\text { Dimensi } \\
\text { Servqual }\end{array}$} & \multirow{2}{*}{ Atribut Pertanyaan } & \multicolumn{5}{|c|}{ Harapan } & \multicolumn{5}{|c|}{ Persepsi } \\
\hline & & & $\mathrm{TH}$ & $\mathrm{KH}$ & $\mathrm{CH}$ & $\mathrm{H}$ & $\mathrm{SH}$ & TP & $\mathrm{KP}$ & $\mathrm{CP}$ & $\mathrm{P}$ & $\mathrm{SP}$ \\
\hline 1 & \multirow{11}{*}{ Tangible } & Tampilan Gedung Perkuliahan Menarik & & & & & & & & & & \\
\hline 2 & & Fasilitas Ruang Perkuliahan Memadai & & & & & & & & & & \\
\hline 3 & & Fasilitas Umum Tersedia & & & & & & & & & & \\
\hline 4 & & Tampilan Staf Karyawan Menarik & & & & & & & & & & \\
\hline 5 & & Tampilan Dosen Menarik & & & & & & & & & & \\
\hline 6 & & Ruang Kuliah Online Tersedia & & & & & & & & & & \\
\hline 7 & & $\begin{array}{l}\text { Infrastruktur Sistem Pembelajaran Online } \\
\text { Tersedia }\end{array}$ & & & & & & & & & & \\
\hline 8 & & Infrastruktur Wifi/ Internet Kampus Tersedia & & & & & & & & & & \\
\hline 9 & & Perpustakaan Online Tersedia & & & & & & & & & & \\
\hline 10 & & Tampilan Website Kampus Menarik & & & & & & & & & & \\
\hline 11 & & Tampilan Sistem E-Learning / Oasis Menarik & & & & & & & & & & \\
\hline 12 & \multirow{9}{*}{ Reliability } & Pelayanan Akademik Ramah & & & & & & & & & & \\
\hline 13 & & Dosen Mampu Mengajar dengan Baik & & & & & & & & & & \\
\hline 14 & & Ada Pembayaran Secara Online & & & & & & & & & & \\
\hline 15 & & Ada Bimbingan Online & & & & & & & & & & \\
\hline 16 & & $\begin{array}{l}\text { Materi Kuliah Sesuai Dengan SAP Dan Soal } \\
\text { Ujian }\end{array}$ & & & & & & & & & & \\
\hline 17 & & Dosen Ramah & & & & & & & & & & \\
\hline 18 & & $\begin{array}{l}\text { Mudah Dalam Memperoleh Bahan } \\
\text { Perkuliahan }\end{array}$ & & & & & & & & & & \\
\hline 19 & & $\begin{array}{l}\text { Mudah Dalam Memperoleh Informasi Secara } \\
\text { Online }\end{array}$ & & & & & & & & & & \\
\hline 20 & & $\begin{array}{l}\text { Penggunaan Sistem Pelayanan Online / } \\
\text { Oasis/ E-Learning Mudah }\end{array}$ & & & & & & & & & & \\
\hline 21 & \multirow{3}{*}{$\begin{array}{l}\text { Respon- } \\
\text { siveness }\end{array}$} & Pelayanan Akademik Cepat & & & & & & & & & & \\
\hline 22 & & Dosen Cepat Dalam Merespons & & & & & & & & & & \\
\hline 23 & & Tanggap terhadap Permasalahan Mahasiswa & & & & & & & & & & \\
\hline 24 & \multirow{4}{*}{$\begin{array}{l}\text { Assu- } \\
\text { rance }\end{array}$} & Data Pada Sistem Aman & & & & & & & & & & \\
\hline 25 & & Ada Peluang Dalam Memperoleh Pekerjaan & & & & & & & & & & \\
\hline 26 & & Kampus Aman & & & & & & & & & & \\
\hline 27 & & Ada Peluang mendapatkan beasiswa & & & & & & & & & & \\
\hline 28 & \multirow{4}{*}{ Empathy } & $\begin{array}{l}\text { Adanya Kemudahan Dalam Berkomunikasi } \\
\text { Dengan Akademik Secara Online }\end{array}$ & & & & & & & & & & \\
\hline 29 & & $\begin{array}{l}\text { Adanya Kemudahan Komunikasi dengan } \\
\text { Bagian Keuangan Secara Online }\end{array}$ & & & & & & & & & & \\
\hline 30 & & $\begin{array}{l}\text { Adanya Kemudahan Komunikasi Dengan } \\
\text { Dosen Secara Online }\end{array}$ & & & & & & & & & & \\
\hline 31 & & $\begin{array}{l}\text { Ada Usaha Memahami Kebutuhan } \\
\text { Mahasiswa }\end{array}$ & & & & & & & & & & \\
\hline
\end{tabular}

Keterangan: TH - tidak mengharapkan, $\mathrm{KH}$ - kurang mengharapkan, $\mathrm{CH}$ - cukup mengharapkan, $\mathrm{H}$ mengharapkan, SH - sangat mengharapkan; TP - tidak puas, KP - kurang puas, CP - cukup puas, P - puas, SP - sangat puas. 


\section{b. Kuesioner Kano}

Atribut pertanyaan dalam Kuesioner Kano menggunakan pertanyaan yang sama dengan Kuesioner Servqual. Pada kuesioner Kano, terdapat dua jenis pertanyaan yaitu Functional Question dan Disfunctional Question. Functional Question merupakan pertanyaan yang menyatakan kondisi yang diharapkan oleh responden jika atribut-atribut suatu produk atau jasa terpenuhi/tersedia. Sedangkan Disfunctional Question menyatakan kondisi yang dirasakan jika fasilitas atau layanan tidak terpenuhi/tidak tersedia. Kuesioner Kano dapat dilihat padaTabel 2.

Tabel 2. Kuesioner kano

\begin{tabular}{|c|c|c|c|c|c|c|}
\hline No. & Atribut Pertanyaan & $\mathbf{s}$ & $\mathbf{M}$ & $\mathbf{N}$ & $\mathbf{T}$ & TS \\
\hline \multirow{2}{*}{1} & Tampilan Gedung Perkuliahan Menarik & & & & & \\
\hline & Tampilan Gedung Perkuliahan Tidak Menarik & & & & & \\
\hline \multirow{2}{*}{2} & Fasilitas Ruang Perkuliahan Memadai & & & & & \\
\hline & Fasilitas Ruang Perkuliahan Tidak Memadai & & & & & \\
\hline \multirow{2}{*}{3} & Fasilitas Umum Tersedia & & & & & \\
\hline & Fasilitas Umum Tidak Tersedia & & & & & \\
\hline \multirow{2}{*}{4} & Tampilan Staf Karyawan Menarik & & & & & \\
\hline & Tampilan Staf Karyawan Tidak Menarik & & & & & \\
\hline \multirow{2}{*}{5} & Tampilan Dosen Menarik & & & & & \\
\hline & Tampilan Dosen Tidak Menarik & & & & & \\
\hline \multirow{2}{*}{6} & Ruang Kuliah Online Tersedia & & & & & \\
\hline & Ruang Kuliah Online Tidak Tersedia & & & & & \\
\hline \multirow{2}{*}{7} & Infrastruktur Sistem Pembelajaran Online Tersedia & & & & & \\
\hline & Infrastruktur Sistem Pembelajaran Online Tidak Tersedia & & & & & \\
\hline \multirow{2}{*}{8} & Infrastruktur Wifi/ Internet Kampus Tersedia & & & & & \\
\hline & Infrastruktur Wifi/ Internet Kampus Tidak Tersedia & & & & & \\
\hline \multirow{2}{*}{9} & Perpustakaan Online Tersedia & & & & & \\
\hline & Perpustakaan Online Tidak Tersedia & & & & & \\
\hline \multirow{2}{*}{10} & Tampilan Website Kampus Menarik & & & & & \\
\hline & Tampilan Website Kampus Tidak Menarik & & & & & \\
\hline \multirow{2}{*}{11} & Tampilan Sistem E-Learning/Oasis Menarik & & & & & \\
\hline & Tampilan Sistem E-Learning/Oasis Tidak Menarik & & & & & \\
\hline \multirow{2}{*}{12} & Pelayanan Akademik Ramah & & & & & \\
\hline & Pelayanan Akademik Tidak Ramah & & & & & \\
\hline \multirow{2}{*}{13} & Dosen Mampu Mengajar dengan Baik & & & & & \\
\hline & Dosen Tidak Mampu Mengajar dengan Baik & & & & & \\
\hline \multirow{2}{*}{14} & Ada Pembayaran Secara Online & & & & & \\
\hline & Tidak Ada Pembayaran Secara Online & & & & & \\
\hline \multirow{2}{*}{15} & Ada Bimbingan Online & & & & & \\
\hline & Tidak Ada Bimbingan Online & & & & & \\
\hline \multirow{2}{*}{16} & Materi Kuliah Sesuai Dengan SAP Dan Soal Ujian & & & & & \\
\hline & Materi Kuliah Tidak Sesuai Dengan SAP Dan Soal Ujian & & & & & \\
\hline \multirow{2}{*}{17} & Dosen Ramah & & & & & \\
\hline & Dosen Tidak Ramah & & & & & \\
\hline \multirow{2}{*}{18} & Mudah Dalam Memperoleh Bahan Perkuliahan & & & & & \\
\hline & Tidak Mudah Dalam Memperoleh Bahan Perkuliahan & & & & & \\
\hline \multirow{2}{*}{19} & Mudah Dalam Memperoleh Informasi Secara Online & & & & & \\
\hline & Tidak Mudah Dalam Memperoleh Informasi Secara Online & & & & & \\
\hline \multirow{2}{*}{20} & Penggunaan Sistem Pelayanan Online / Oasis/ E-Learning Mudah & & & & & \\
\hline & Penggunaan Sistem Pelayanan Online / Oasis/ E-Learning Tidak Mudah & & & & & \\
\hline
\end{tabular}


Tabel 2. Kuesioner kano (lanjutan)

\begin{tabular}{|c|c|c|c|c|c|c|}
\hline No. & Atribut Pertanyaan & $\mathbf{S}$ & $\mathbf{M}$ & $\mathbf{N}$ & $\mathbf{T}$ & TS \\
\hline \multirow{2}{*}{21} & Pelayanan Akademik Cepat & & & & & \\
\hline & Pelayanan Akademik Tidak Cepat & & & & & \\
\hline \multirow{2}{*}{22} & Dosen Cepat Dalam Merespons & & & & & \\
\hline & Dosen Tidak Cepat Dalam Merespons & & & & & \\
\hline \multirow{2}{*}{23} & Tanggap Terhadap Permasalahan Mahasiswa & & & & & \\
\hline & Tidak Tanggap Terhadap Permasalahan Mahasiswa & & & & & \\
\hline \multirow{2}{*}{24} & Data Pada Sistem Aman & & & & & \\
\hline & Data Pada Sistem Tidak Aman & & & & & \\
\hline \multirow{2}{*}{25} & Ada Peluang Dalam Memperoleh Pekerjaan & & & & & \\
\hline & Tidak Ada Peluang Dalam Memperoleh Pekerjaan & & & & & \\
\hline \multirow{2}{*}{26} & Kampus Aman & & & & & \\
\hline & Kampus Tidak Aman & & & & & \\
\hline \multirow{2}{*}{27} & Ada Peluang mendapatkan beasiswa & & & & & \\
\hline & Tidak Ada Peluang mendapatkan beasiswa & & & & & \\
\hline \multirow{2}{*}{28} & Adanya Kemudahan Dalam Berkomunikasi Dengan Akademik Secara Online & & & & & \\
\hline & Tidak Adanya Kemudahan Dalam Berkomunikasi Dengan Akademik Secara Online & & & & & \\
\hline \multirow{2}{*}{29} & Adanya Kemudahan Komunikasi dengan Bagian Keuangan Secara Online & & & & & \\
\hline & Tidak Adanya Kemudahan Komunikasi dengan Bagian Keuangan Secara Online & & & & & \\
\hline \multirow{2}{*}{30} & Adanya Kemudahan Komunikasi Dengan Dosen Secara Online & & & & & \\
\hline & Tidak Adanya Kemudahan Komunikasi Dengan Dosen Secara Online & & & & & \\
\hline \multirow{2}{*}{31} & Ada Usaha Memahami Kebutuhan Mahasiswa & & & & & \\
\hline & Tidak Ada Usaha Memahami Kebutuhan Mahasiswa & & & & & \\
\hline
\end{tabular}

c. Sampel

Populasi dalam penelitian ini adalah Mahasiswa angkatan 2016 yang berjumlah 369 Mahasiswa. Terdiri dari 176 Mahasiswa Teknik Industri, 133 Mahasiswa Teknik Informatika, dan 60 Mahasiswa Desain Komunikasi Visual.

Penentuan ukuran sampel pada penelitian ini menggunakan Rumus Slovin, yaitu:

Dimana :

$$
n=\frac{N}{1+N \cdot\left(e^{2}\right)}
$$

Pers. 1

$$
\begin{aligned}
& \mathrm{n}=\text { Jumlah Sampel } \\
& \mathrm{N}=\text { Jumlah Populasi } \\
& \mathrm{e}=\text { Toleransi Error }
\end{aligned}
$$

Perhitungannya adalah sebagai berikut:

$$
\begin{gathered}
n=\frac{369}{1+369 \cdot\left(0,10^{2}\right)} \\
n=78,68 \approx 79 \text { Mahasiswa }
\end{gathered}
$$

Sehingga, dengan tingkat toleransi kesalahan $10 \%$ didapat bahwa ukuran sampel pada penelitian ini adalah sebesar 79 Mahasiswa.

\section{Pengolahan Data}

Setelah dilakukan pengumpulan data, pembuatan, penyebaran kuesioner, langkah selanjutnya adalah melakukan pengolahan data.

a. Uji Validitas

Uji validitas dilakukan terhadap semua pertanyaan pada setiap responden. Setelah dilakukan Uji Validitas, dengan tingkat kepercayaan $95 \%$, maka semua data variabel dinyatakan Valid, dimana $r$ hitung $>r$ tabel. Tabel 3 menampilkan hasil uji validitias.

b. Uji Reliabilitas

Setelah dilakukan uji validitas, langkah selanjutnya yaitu melakukan Uji Reliabilitas. Dimana dasar pengambilan keputusannya, dikatakan Reliabel jika nilai Cronbach's Alpha> 6.0. Hasil perhitungan menunjukkan nilai Cronbach's Alpha lebih besar dari 0.60, sehingga data kuesioner tersebut dinyatakan reliabel. Tabel 4 menampilkan hasil uji reliabilitas.

\section{Hasil dan Diskusi}

Untuk mengetahui nilai gap dari kinerja dan harapan mahasiswa terhadap pelayanan yang diberikan, maka dilakukan pengolahan data kuesioner servqual. Tabel 5 menunjukkan nilai gap bernilai negatif untuk semua atribut pelayanan. Ini menunjukkan bahwa semua 
kinerja pelayanan yang diberikan pihak kampus masih di bawah harapan dari mahasiswa.

Tabel 3. Hasil uji validitas

\begin{tabular}{|c|c|c|c|c|c|c|}
\hline \multirow{2}{*}{$\begin{array}{c}\text { No. } \\
\text { Atribut }\end{array}$} & $\begin{array}{c}\text { Harapan } \\
\text { tabel }\end{array}$ & $\begin{array}{c}r \\
\text { hitung }\end{array}$ & Ket. & $\begin{array}{c}r \\
\text { tabel }\end{array}$ & $\begin{array}{c}r \\
\text { hitung }\end{array}$ & \multirow{2}{*}{ Ket. } \\
\hline 1 & 0,221 & 0,723 & Valid & 0,221 & 0,515 & Valid \\
\hline 2 & 0,221 & 0,752 & Valid & 0,221 & 0,548 & Valid \\
\hline 3 & 0,221 & 0,751 & Valid & 0,221 & 0,594 & Valid \\
\hline 4 & 0,221 & 0,288 & Valid & 0,221 & 0,521 & Valid \\
\hline 5 & 0,221 & 0,263 & Valid & 0,221 & 0,517 & Valid \\
\hline 6 & 0,221 & 0,489 & Valid & 0,221 & 0,507 & Valid \\
\hline 7 & 0,221 & 0,631 & Valid & 0,221 & 0,479 & Valid \\
\hline 8 & 0,221 & 0,682 & Valid & 0,221 & 0,479 & Valid \\
\hline 9 & 0,221 & 0,603 & Valid & 0,221 & 0,539 & Valid \\
\hline 10 & 0,221 & 0,478 & Valid & 0,221 & 0,648 & Valid \\
\hline 11 & 0,221 & 0,580 & Valid & 0,221 & 0,703 & Valid \\
\hline 12 & 0,221 & 0,591 & Valid & 0,221 & 0,668 & Valid \\
\hline 13 & 0,221 & 0,571 & Valid & 0,221 & 0,493 & Valid \\
\hline 14 & 0,221 & 0,586 & Valid & 0,221 & 0,560 & Valid \\
\hline 15 & 0,221 & 0,691 & Valid & 0,221 & 0,465 & Valid \\
\hline 16 & 0,221 & 0,764 & Valid & 0,221 & 0,619 & Valid \\
\hline 17 & 0,221 & 0,508 & Valid & 0,221 & 0,511 & Valid \\
\hline 18 & 0,221 & 0,720 & Valid & 0,221 & 0,464 & Valid \\
\hline 19 & 0,221 & 0,787 & Valid & 0,221 & 0,638 & Valid \\
\hline 20 & 0,221 & 0,693 & Valid & 0,221 & 0,666 & Valid \\
\hline 21 & 0,221 & 0,775 & Valid & 0,221 & 0,741 & Valid \\
\hline 22 & 0,221 & 0,633 & Valid & 0,221 & 0,522 & Valid \\
\hline 23 & 0,221 & 0,794 & Valid & 0,221 & 0,722 & Valid \\
\hline 24 & 0,221 & 0,676 & Valid & 0,221 & 0,498 & Valid \\
\hline 25 & 0,221 & 0,759 & Valid & 0,221 & 0,505 & Valid \\
\hline 26 & 0,221 & 0,644 & Valid & 0,221 & 0,329 & Valid \\
\hline 27 & 0,221 & 0,67 & Valid & 0,221 & 0,480 & Valid \\
\hline 28 & 0,221 & 0,666 & Valid & 0,221 & 0,741 & Valid \\
\hline 29 & 0,221 & 0,677 & Valid & 0,221 & 0,727 & Valid \\
\hline 30 & 0,221 & 0,581 & Valid & 0,221 & 0,563 & Valid \\
\hline 31 & 0,221 & 0,652 & Valid & 0,221 & 0,655 & Valid \\
\hline
\end{tabular}

Tabel 4. Hasil uji reliabilitas

\begin{tabular}{|c|c|c|c|}
\hline $\begin{array}{c}\text { Jenis } \\
\text { Kuesioner }\end{array}$ & $\begin{array}{c}\text { Nilai } \\
\text { Cronbach's } \\
\text { Alpha }\end{array}$ & $\begin{array}{c}\text { Nilai } \\
\text { Cronbach's } \\
\text { Alpha } \\
\text { (minimum) }\end{array}$ & Keterangan \\
\hline Harapan & 0,949 & 0,6 & Reliabel \\
\hline Persepsi & 0,931 & 0,6 & Reliabel \\
\hline
\end{tabular}

Langkah selanjutnya adalah menentukan kategori Kano untuk semua atribut Servqual berdasarkan functional dan dysfunctional Question. Dalam menentukan kategori Kano untuk tiap-tiap atribut layanan atau pertanyaan, menggunakan Blauth Formula sebagai berikut:
Jika (one-dimentional + Attractive + must be) $>$ (Indifferent + reverse + questionable $)$ maka grade diperoleh dari yang paling maksimum dari (one-dimentional, Attractive, mustbe)

Jika (one-dimentional + Attractive + must be) $<$ (Indifferent + reverse + questionable $)$ maka grade diperoleh dari yang paling maksimum dari (Indifferent, reverse, questionable).

Adapun hasil dari penentuan kategori Kano untuk semua atribut Servqual dapat dilihat pada Tabel 6.

Tabel 6 menunjukkan bahwa atribut layanan $1,2,3,4,5,7,11,14,15,16,21,22$, 23, 30 dan 31 termasuk ke dalam kategori Indifferent. Atribut layanan 6, 8, 9, 12, 13, 18, 20, 24, 26, 27, 28 dan 29 termasuk ke dalam kategori One Dimentional. Atribut layanan 10, 17 dan 19 termasuk kategori attractive. Atribut layanan 25 termasuk kategori must be.

\section{Integrasi Servqual, Kano dan QFD}

Metode QFD digunakan untuk mengetahui prioritas rencana teknis yang digunakan dalam memenuhi kebutuhan mahasiswa (customer requirement). Pengolahan data metode QFD diawali dengan menentukan atribut perbaikan (what).

Atribut perbaikan ini merupakan hasil perhitungan integrasi metode Servqual dan Kano, dimana atribut ini yang memiliki nilai gap lemah/negatif (weak) dan termasuk kedalam kategori Kano A (attractive), $\mathrm{O}$ (one dimentional), dan M (must be), yaitu :

1. Ruang kuliah online tersedia

2. Infrastruktur wifi/ internet kampus tersedia

3. Perpustakaan online tersedia

4. Tampilan website kampus menarik

5. Pelayanan akademik ramah

6. Dosen mampu mengajar dengan baik

7. Dosen yang ramah

8. Mudah dalam memperoleh bahan perkuliahan

9. Mudah dalam memperoleh informasi secara online

10. Penggunaan sistem pelayanan online / oasis/ e-learning mudah

11. Data pada sistem aman

12. Ada peluang dalam memperoleh pekerjaan 
Tabel 5. Nilai gap dari kinerja dan harapan mahasiswa

\begin{tabular}{|c|c|c|c|c|c|}
\hline No. & $\begin{array}{l}\text { Dimensi } \\
\text { Servqual }\end{array}$ & Atribut Pertanyaan & Kinerja & Harapan & Gap \\
\hline 1 & \multirow{11}{*}{ Tangible } & Tampilan Gedung Perkuliahan Menarik & 2,44 & 3,81 & $-1,37$ \\
\hline 2 & & Fasilitas Ruang Perkuliahan Memadai & 2,47 & 3,95 & $-1,48$ \\
\hline 3 & & Fasilitas Umum Tersedia & 2,03 & 3,80 & $-1,77$ \\
\hline 4 & & Tampilan Staf Karyawan Menarik & 3,04 & 3,46 & $-0,42$ \\
\hline 5 & & Tampilan Dosen Menarik & 3,47 & 3,73 & $-0,27$ \\
\hline 6 & & Ruang Kuliah Online Tersedia & 2,34 & 3,28 & $-0,94$ \\
\hline 7 & & Infrastruktur Sistem Pembelajaran Online Tersedia & 2,28 & 3,48 & $-1,20$ \\
\hline 8 & & Infrastruktur Wifi/ Internet Kampus Tersedia & 2,19 & 3,91 & $-1,72$ \\
\hline 9 & & Perpustakaan Online Tersedia & 2,14 & 3,76 & $-1,62$ \\
\hline 10 & & Tampilan Website Kampus Menarik & 2,89 & 3,77 & $-0,89$ \\
\hline 11 & & Tampilan Sistem E-Learning / Oasis Menarik & 2,95 & 3,87 & $-0,92$ \\
\hline 12 & \multirow{9}{*}{ Reliability } & Pelayanan Akademik Ramah & 2,96 & 4,11 & $-1,15$ \\
\hline 13 & & Dosen Mampu Mengajar dengan Baik & 3,32 & 4,39 & $-1,08$ \\
\hline 14 & & Ada Pembayaran Secara Online & 2,95 & 4,05 & $-1,10$ \\
\hline 15 & & Ada Bimbingan Online & 2,97 & 3,92 & $-0,95$ \\
\hline 16 & & Materi Kuliah Sesuai Dengan SAP Dan Soal Ujian & 2,92 & 4,11 & $-1,19$ \\
\hline 17 & & Dosen Ramah & 3,57 & 4,29 & $-0,72$ \\
\hline 18 & & Mudah Dalam Memperoleh Bahan Perkuliahan & 2,99 & 4,33 & $-1,34$ \\
\hline 19 & & Mudah Dalam Memperoleh Informasi Secara Online & 2,97 & 4,32 & $-1,34$ \\
\hline 20 & & $\begin{array}{l}\text { Penggunaan Sistem Pelayanan Online / Oasis/ E-Learning } \\
\text { Mudah }\end{array}$ & 3,19 & 4,41 & $-1,22$ \\
\hline 21 & \multirow{3}{*}{ Responsiveness } & Pelayanan Akademik Cepat & 2,67 & 4,25 & $-1,58$ \\
\hline 22 & & Dosen Cepat Dalam Merespons & 3,08 & 4,38 & $-1,30$ \\
\hline 23 & & Tanggap terhadap Permasalahan Mahasiswa & 2,80 & 4,35 & $-1,56$ \\
\hline 24 & \multirow{4}{*}{ Assurance } & Data Pada Sistem Aman & 2,99 & 4,30 & $-1,32$ \\
\hline 25 & & Ada Peluang Dalam Memperoleh Pekerjaan & 2,76 & 4,43 & $-1,67$ \\
\hline 26 & & Kampus Aman & 3,28 & 4,29 & $-1,01$ \\
\hline 27 & & Ada Peluang mendapatkan beasiswa & 2,67 & 4,43 & $-1,76$ \\
\hline 28 & \multirow{4}{*}{ Emphaty } & $\begin{array}{l}\text { Adanya Kemudahan Dalam Berkomunikasi Dengan } \\
\text { Akademik Secara Online }\end{array}$ & 2,82 & 4,27 & $-1,44$ \\
\hline 29 & & $\begin{array}{l}\text { Adanya Kemudahan Komunikasi dengan Bagian Keuangan } \\
\text { Secara Online }\end{array}$ & 2,73 & 4,24 & $-1,51$ \\
\hline 30 & & $\begin{array}{l}\text { Adanya Kemudahan Komunikasi Dengan Dosen Secara } \\
\text { Online }\end{array}$ & 3,16 & 4,37 & $-1,20$ \\
\hline 31 & & Ada Usaha Memahami Kebutuhan Mahasiswa & 2,67 & 4,41 & $-1,73$ \\
\hline
\end{tabular}

Tabel 6. Penentuan kategori kano seluruh atribut

\begin{tabular}{|c|c|c|c|}
\hline No & Dimensi & Atribut Layanan & Kategori Kano \\
\hline 1 & \multirow{11}{*}{ Tangible } & Tampilan Gedung Perkuliahan Menarik & Indifferent \\
\hline 2 & & Fasilitas Ruang Perkuliahan Memadai & Indifferent \\
\hline 3 & & Fasilitas Umum Tersedia & Indifferent \\
\hline 4 & & Tampilan Staf Karyawan Menarik & Indifferent \\
\hline 5 & & Tampilan Dosen Menarik & Indifferent \\
\hline 6 & & Ruang Kuliah Online Tersedia & One Dimentional \\
\hline 7 & & Infrastruktur Sistem Pembelajaran Online Tersedia & Indifferent \\
\hline 8 & & Infrastruktur Wifi/ Internet Kampus Tersedia & One Dimentional \\
\hline 9 & & Perpustakaan Online Tersedia & One Dimentional \\
\hline 10 & & Tampilan Website Kampus Menarik & Attractive \\
\hline 11 & & Tampilan Sistem E-Learning / Oasis Menarik & Indifferent \\
\hline 12 & \multirow{6}{*}{ Reliability } & Pelayanan Akademik Ramah & One Dimentional \\
\hline 13 & & Dosen Mampu Mengajar dengan Baik & One Dimentional \\
\hline 14 & & Ada Pembayaran Secara Online & Indifferent \\
\hline 15 & & Ada Bimbingan Online & Indifferent \\
\hline 16 & & Materi Kuliah Sesuai Dengan SAP Dan Soal Ujian & Indifferent \\
\hline 17 & & Dosen Ramah & Attractive \\
\hline
\end{tabular}


Tabel 6. Penentuan kategori kano seluruh atribut (lanjutan)

\begin{tabular}{|c|c|c|c|}
\hline No & Dimensi & Atribut Layanan & Kategori Kano \\
\hline 18 & \multirow{3}{*}{ Reliability } & Mudah Dalam Memperoleh Bahan Perkuliahan & One Dimentional \\
\hline 19 & & Mudah Dalam Memperoleh Informasi Secara Online & Attractive \\
\hline 20 & & Penggunaan Sistem Pelayanan Online / Oasis/ E-Learning Mudah & One Dimentional \\
\hline 21 & \multirow{3}{*}{ Responsiveness } & Pelayanan Akademik Cepat & Indifferent \\
\hline 22 & & Dosen Cepat Dalam Merespon & Indifferent \\
\hline 23 & & Tanggap terhadap Permasalahan Mahasiswa & Indifferent \\
\hline 24 & \multirow{4}{*}{ Assurance } & Data Pada Sistem Aman & One Dimentional \\
\hline 25 & & Ada Peluang Dalam Memperoleh Pekerjaan & Must Be \\
\hline 26 & & Kampus Aman & One Dimentional \\
\hline 27 & & Ada Peluang mendapatkan beasiswa & One Dimentional \\
\hline 28 & \multirow{4}{*}{ Emphaty } & $\begin{array}{l}\text { Adanya Kemudahan Dalam Berkomunikasi Dengan Akademik Secara } \\
\text { Online }\end{array}$ & One Dimentional \\
\hline 29 & & Adanya Kemudahan Komunikasi dengan Bagian Keuangan Secara Online & One Dimentional \\
\hline 30 & & Adanya Kemudahan Komunikasi Dengan Dosen Secara Online & Indifferent \\
\hline 31 & & Ada Usaha Memahami Kebutuhan Mahasiswa & Indifferent \\
\hline
\end{tabular}

13. Kampus yang aman

14. Ada peluang mendapatkan beasiswa

15. Adanya kemudahan dalam berkomunikasi dengan akademik secara online

16. Adanya kemudahan komunikasi dengan bagian keuangan secara online

Langkah selanjutnya menentukan Prioritas Perbaikan (Importance Level of What) dan Adjusted Imprortance. Nilai Importance level of what merupakan hasil perkalian Gap Score dengan tingkat kepentingan. Sedangkan nilai Adjusted Imprortance di dapat dari hasil perkalian antara Importance level of what dengan bobot skor kano, dengan ketentuan: score 4 untuk kategori A (attractive), score 2 untuk kategori O (one dimentional), dan score 1 untuk kategori $\mathrm{M}$ (must be).

Tabel 7 menunjukkan nilai prioritas perbaikan, dengan urutan prioritas sebagai berikut:

1. Mudah Dalam Memperoleh Informasi Secara online, nilai importance level 23,17

2. Ada Peluang mendapatkan beasiswa, nilai importance level 15,59

3. Infrastruktur Wifi/ Internet Kampus Tersedia, nilai importance level 13,47

4. Tampilan Website Kampus Menarik, nilai importance level 13,37

5. Adanya Kemudahan Komunikasi dengan Bagian Keuangan Secara online, nilai importance level 12,78

6. Dosen yang Ramah, nilai importance level 12,38
7. Adanya Kemudahan Dalam Berkomunikasi Dengan Akademik Secara online, nilai importance level 12,31

8. Perpustakaan Online Tersedia, nilai importance level 12,18

9. Mudah Dalam Memperoleh Bahan Perkuliahan, nilai importance level 11,62

10. Data Pada Sistem Aman, nilai importance level 11,33

11. Penggunaan Sistem Pelayanan Online / Oasis/ E-Learning Mudah, nilai importance level 10,71

12. Pelayanan Akademik Ramah, nilai importance level 9,48

13. Dosen Mampu Mengajar dengan Baik, nilai importance level 9,45

14. Kampus yang Aman, nilai importance level 8,69

15. Ada Peluang Dalam Memperoleh Pekerjaan, nilai importance level 7,40

16. Ruang Kuliah Online Tersedia, nilai importance level 6,14

Untuk mengatasi atribut perbaikan tersebut, langkah selanjutnya menentukan Respons Teknis (How). Respons teknis merupakan perbaikan pelayanan yang dilakukan pihak kampus untuk memenuhi kebutuhan mahasiswa. Respons teknis ini hasil diskusi dengan pihak kampus, yaitu:

a. Membangun pusat informasi terpadu secara online

b. Memperbanyak kerja sama untuk beasiswa

c. Meningkatkan kualitas internet/wifi kampus 
Tabel 7. Nilai prioritas perbaikan

\begin{tabular}{|c|l|c|c|c|c|}
\hline No & \multicolumn{1}{|c|}{ Atribut Layanan } & $\begin{array}{c}\text { Importance } \\
\text { level of } \\
\text { what }\end{array}$ & Kategori Kano & $\begin{array}{c}\text { Score } \\
\text { Kano }\end{array}$ & $\begin{array}{c}\text { Adjusted } \\
\text { Importance } \\
\text { Level }\end{array}$ \\
\hline 6 & Ruang Kuliah Online Tersedia & 3,07 & One Dimensional & 2 & 6,14 \\
\hline 8 & Infrastruktur Wifi/ Internet Kampus Tersedia & 6,73 & One Dimensional & 2 & 13,47 \\
\hline 9 & Perpustakaan Online Tersedia & 6,09 & One Dimensional & 2 & 12,18 \\
\hline 10 & Tampilan Website Kampus Menarik & 3,34 & Attractive & 4 & 13,37 \\
\hline 12 & Pelayanan Akademik Ramah & 4,74 & One Dimensional & 2 & 9,48 \\
\hline 13 & Dosen Mampu Mengajar dengan Baik & 4,73 & One Dimensional & 2 & 9,45 \\
\hline 17 & Dosen yang Ramah & 3,10 & Attractive & 4 & 12,38 \\
\hline 18 & Mudah Dalam Memperoleh Bahan Perkuliahan & 5,81 & One Dimensional & 2 & 11,62 \\
\hline 19 & Mudah Dalam Memperoleh Informasi Secara Online & 5,79 & Attractive & 4 & 23,17 \\
\hline 20 & Penggunaan Sistem Pelayanan Online / Oasis/ E- & 5,35 & One Dimensional & 2 & 10,71 \\
\hline 24 & Data Pada Sistem Aman & 5,67 & One Dimensional & 2 & 11,33 \\
\hline 25 & Ada Peluang Dalam Memperoleh Pekerjaan & 7,40 & Must Be & 1 & 7,40 \\
\hline 26 & Kampus yang Aman & 4,35 & One Dimensional & 2 & 8,69 \\
\hline 27 & Ada Peluang mendapatkan beasiswa & 7,80 & One Dimensional & 2 & 15,59 \\
\hline 28 & $\begin{array}{l}\text { Adanya Kemudahan Dalam Berkomunikasi Dengan } \\
\text { Akademik Secara Online }\end{array}$ & 6,16 & One Dimensional & 2 & 12,31 \\
\hline 29 & $\begin{array}{l}\text { Adanya Kemudahan Komunikasi dengan Bagian } \\
\text { Keuangan Secara Online }\end{array}$ & 6,39 & One Dimensional & 2 & 12,78 \\
\hline
\end{tabular}

d. Menjadikan website kampus lebih hidup (up to date)

e. Membangun sistem pelayanan online terpadu

f. Meningkatkan kualitas dosen dengan pelatihan-pelatihan dosen

g. Membangun perpustakaan online

h. Meningkatkan keamanan kampus

i. Memperbanyak kerja sama dengan institusi lain (BUMN, swasta, dII)

j. Meningkatkan infrastruktur perkuliahan online

k. Meningkatkan sistem Data Security

I. Menerapkan $5 S$ (senyum, salam, sapa, sopan dan santun)

$\mathrm{m}$. Membuka perkuliahan online

n. Meningkatkan Sosialisasi sistem pelayanan

Selanjutnya dikembangkan lebih lanjut dengan menyusun Matriks $\mathrm{HOQ}$, lihat Gambar 5.

Berdasarkan $\mathrm{HOQ}$ yang sudah dibuat, didapatkan urutan prioritas respons teknis sebagai berikut : membangun pusat informasi terpadu secara online dengan bobot $21,04 \%$, membangun sistem pelayanan online terpadu dengan bobot $12,06 \%$, membuka perkuliahan online bobot $8,88 \%$, membangun perpustakaan online dengan bobot $7,89 \%$, menerapkan $5 \mathrm{~S}$ (senyum, salam, sapa, sopan dan santun) dengan bobot $7,25 \%$, menjadikan website kampus lebih hidup (up to date) dengan bobot $6,99 \%$, memperbanyak sumber-sumber beasiswa dengan bobot $5,99 \%$, meningkatkan kualitas internet/wifi kampus dengan bobot $5,97 \%$, meningkatkan kualitas dosen dengan pelatihan-pelatihan dengan bobot $5,40 \%$, meningkatkan sistem Data Security dengan bobot 4,44\%, memperbanyak kerja sama dengan institusi lain (BUMN, swasta,dll) dengan bobot $4,18 \%$, meningkatkan program magang bersertifikat dengan bobot 3,03\%, meningkatkan keamanan kampus dengan bobot 2,88\%, meningkatkan infrastruktur perkuliahan online dengan bobot 2,04\%, meningkatkan sosialisasi sistem pelayanan dengan bobot $2,04 \%$, dan membangun jaringan Alumni dengan bobot $0,82 \%$.

\section{Kesimpulan}

Setelah dilakukan pengolahan data dan analisa, maka dapat ditarik beberapa kesimpulan yaitu:

1. Berdasarkan Metode Servqual, nilai gap seluruh atribut pelayanan yang diberikan pihak kampus bernilai negatif atau kinerja pelayanan masih belum mampu memenuhi harapan dari mahasiswa.

2. Berdasarkan Integrasi Metode Servqual, Kano dan QFD, atribut pelayanan yang perlu dilakukan perbaikan adalah atribut yang 
memiliki kinerja rendah, yaitu atribut yang mempunyai nilai gap negatif pada metode

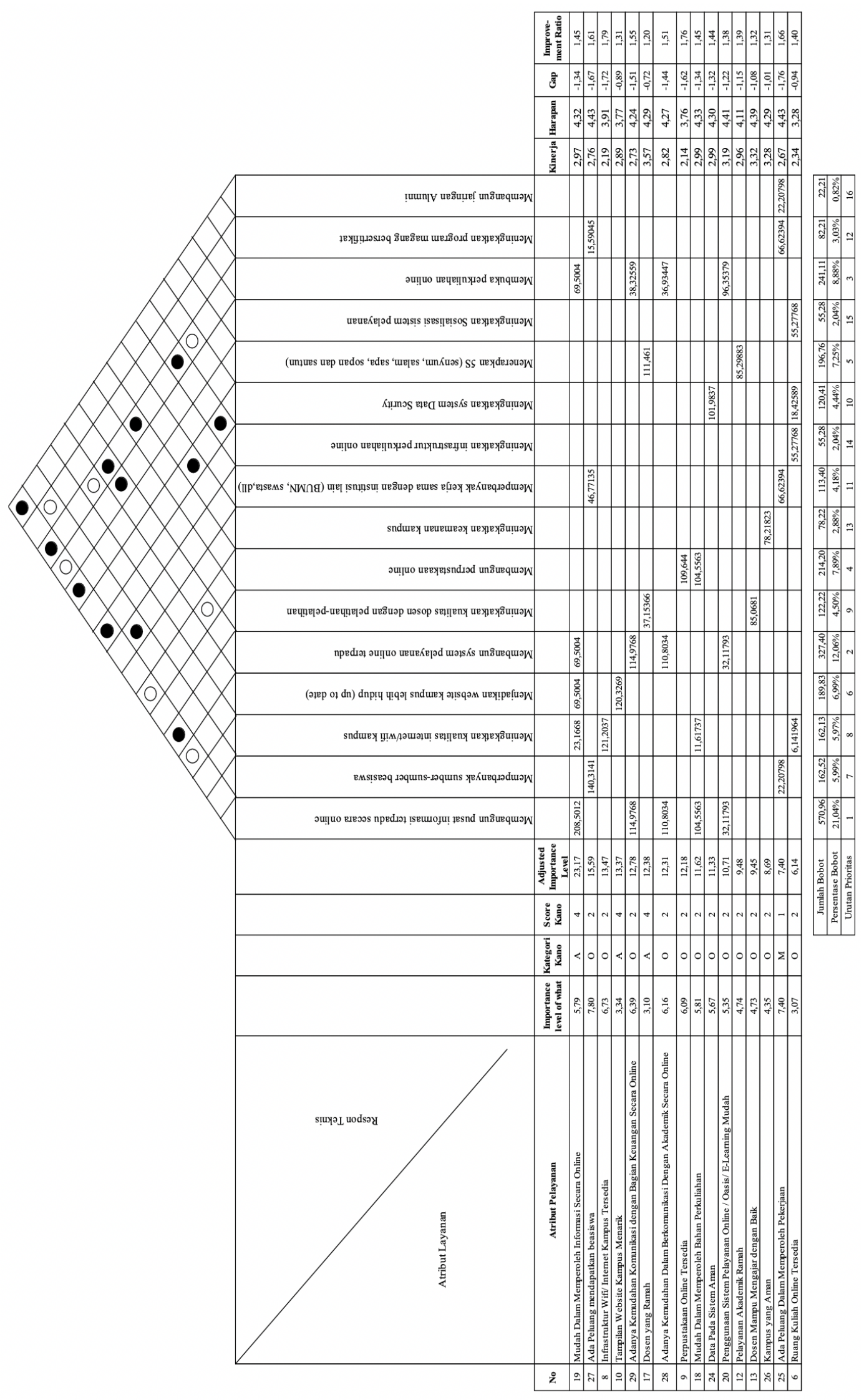

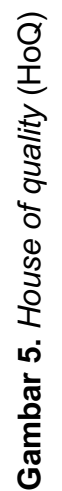


3. Servqual dan termasuk kategori A (attractive), $\mathrm{O}$ (one dimentional), dan $\mathrm{M}$ (must be) pada metode Kano. Kemudian dilakukan perhitungan importance level, sehingga urutan perioritas atribut pelayanannya adalah mudah dalam memperoleh informasi secara online (nilai importance level 23,17), ada peluang mendapatkan beasiswa (nilai importance level 15,59), infrastruktur wifi/ internet kampus tersedia (nilai importance level 13,47), tampilan website kampus menarik (nilai importance level 13,37), adanya kemudahan komunikasi dengan bagian keuangan secara online (nilai importance level 12,78), dosen yang ramah (nilai importance level 12,38), adanya kemudahan dalam berkomunikasi dengan akademik secara online (nilai importance level 12,31), perpustakaan online tersedia (nilai importance level 12,18), mudah dalam memperoleh bahan perkuliahan (nilai importance level 11,62), data pada sistem aman (nilai importance level 11,33), penggunaan sistem pelayanan online/ oasis/ e-learning mudah (nilai importance level 10,71), pelayanan akademik ramah, (nilai importance level 9,48), dosen mampu mengajar dengan baik (nilai importance level 9,45), kampus yang aman (nilai importance level 8,69), ada peluang dalam memperoleh pekerjaan (nilai importance level 7,40 ), dan ruang kuliah online tersedia (nilai importance level 6,14).

4. Implikasi dari penelitian ini memberikan rekomendasi kepada Sekolah Tinggi XYZ untuk meningkatkan kualitas pelayanan berdasarkan prioritas respons teknis sebagai berikut: membangun pusat informasi terpadu secara online (bobot $21,04 \%$ ), membangun sistem pelayanan online terpadu (bobot 12,06\%), membuka perkuliahan online (bobot 8,88\%), membangun perpustakaan online (bobot $7,89 \%$ ), menerapkan $5 \mathrm{~S}$ (senyum, salam, sapa, sopan dan santun) (bobot 7,25\%), menjadikan website kampus lebih hidup (up to date) (bobot 6,99\%), memperbanyak sumber-sumber beasiswa (bobot 5,99\%), meningkatkan kualitas internet/wifi kampus (bobot 5,97\%), meningkatkan kualitas dosen dengan pelatihan-pelatihan (bobot 5,40\%), meningkatkan sistem Data Scurity (bobot 4,44\%), memperbanyak kerja sama dengan institusi lain (BUMN, swasta, dll) (bobot $4,18 \%$ ), meningkatkan program magang bersertifikat (bobot 3,03\%), meningkatkan keamanan kampus (bobot 2,88\%), meningkatkan infrastruktur perkuliahan online (bobot 2,04\%), meningkatkan Sosialisasi sistem pelayanan (bobot 2,04\%), dan membangun jaringan Alumni (bobot $0,82 \%)$

\section{Daftar Pustaka}

Baki, B., Basfirinci, C. S., Cilingir, Z., \& Murat AR, I., (2009). An application of integrating SERVQUAL and Kano's model into QFD for logistics services: A case study from Turkey. Asia Pacific Journal of Marketing and Logistics, 21(1), 106-126.

Chen, C. C., \& Chuang, M. C. (2008). Integrating the Kano model into a robust design approach to enhance customer satisfaction with product design. International Journal of Production Economics, 114(2), 667-681.

Gupta, P., \& Srivastava, R. K. (2012). Integrating SERVQUAL and Kano model into QFD for customer satisfaction of the hotel service industry. MIT International Journal of Mechanical Engineering, 2(1), 4554.

Hartanto, C.F.B, Rusdarti, \& Abdurrahman. (2009). Tantangan Pendidikan Vokasi di Era Revolusi Industri 4.0 dalam Menyiapkan Sumber Daya Manusia yang Unggul. Prosiding Seminar Nasional Pascasarjana UNNES.

Hartono, M., Chuan, T. K., \& Peacock, J. B. (2013). Applying kansei engineering, the Kano model and QFD to services. International Journal Services, Economics and Management, 5(3), 256-274.

Jing-Hua, L., Lei, X., \& Xiu-Lan, W. (2009). New service development using GAP-based QFD: a mobile telecommunication case. International Journal of Services Technology \& Management, 12(2), 146-174.

Oktafiara S, A., Hidayat, W., \& L, S., (2017). Effect of Price, Promotion, and Service Quality on Customer Satisfaction (Study at Astra Motor Siliwangi AHASS0002 
Workshop Semarang). Journal of Business Administration.

Parasuraman, A., Zeithaml, V. A, \& Berry, L. (1985). A Conceptual Model of Service Quality and Implication for Future Research, Journal of Marketing.

Parasuraman, A., Zeithaml, V. A., \& Berry, L. L. (1990). Delivering quality service: balancing customer perceptions and expectations. New York: The Free Press.

Russel, R. S. \& Taylor, B. W. (2003). Operation Management. New Jersey: Prentice Hall.
Tam, P. T. \& Thuy, B. V. (2017). The Industry 4.0 Factor Affecting The Service Quality Of Commercial Banks In Dong Nai Province., European Journal of Accounting Auditing and Finance Research, 5(9), 81-91.

Tjiptono, F. (2011). Strategi Pemasaran. Yogyakarta: Andi Ofset.

Wijaya, T. (2018). Manajemen Kualitas Jasa. Jakarta: PT Indeks. 